\title{
ŠTÁTNE INTERVENCIE A TRH PRIVATE EQUITY V STREDNEJ A VÝCHODNEJ EURÓPE
}

\author{
Elena Fetisovová, Eduard Hyránek, Ladislav Nagy
}

Kl’účové slová:

Európa, malé a stredné podniky, private equity, rizikové investície, rizikový kapitál, trh rizikového kapitálu, štátne intervencie

\section{Key words:}

Europe, small and medium-sized enterprises, private equity, risky investment, venture capital, venture capital market, state intervention

\begin{abstract}
Abstrakt
Pôvodné chápanie termínu rizikový kapitál sa postupom času rozšírilo. Potvrdzuje to významný počet fondov v Európe a USA, ktoré boli špecializované výlučne na investovanie do počiatočného rozvoja. Diverzifikovali svoje investície a predmet svojej činnosti rozšírili na celý okruh rizikových investícií alebo sa zameriavali len na rozvojové financovanie. Zmena obsahu pojmu rizikový kapitál vlastne symbolizovala rozdelenie trhu rizikového kapitálu na dve časti: trh klasického rizikového kapitálu a trh rozvojového kapitálu. Rizikový kapitál predstavuje investíciu do základného imania podniku, ktorý nemá žiadnu históriu. Cielom rozvojového kapitálu je financovat' rýchly rast a realizáciu inovatívnych zámerov podnikov s históriou, ktoré nemajú dostatok kapitálu. Príspevok prezentuje rôzne názory o štátnych intervenciách na trhu private equity. Významná pozornost' je venovaná predpokladom vývoja formálneho trhu private equity v strednej a východnej Európe. Budúci rozvoj trhu private equity $\mathrm{v}$ krajinách daného regiónu závisí od miery dosahov globálnej recesie a od predpokladov efektívneho fungovania trhu. Značný objem nazhromaždeného kapitálu pred krízou ešte len čaká na investovanie, a preto nemôžeme $\mathrm{v}$ súčasnom období očakávat' drastickú recesiu trhu rizikového kapitálu v štátoch analyzovaného regiónu.
\end{abstract}

\begin{abstract}
Primal comprehension of risk capital has been enlarged gradually in the course of time. It is approved by significant amount of funds in Europe and in the USA, which was explicitly specialized for investing in initial development. They diversified their investments and enlarged the subject of their activity to all sphere of risk investments, or focused in development financing only. Change of concept of a meaning risk capital symbolized diversification market of risk capital into two parts: market of classic risk capital and market of development capital. Risk capital is investment in equity of enterprise, which is without history. Objective of capital development is financing of quick growth and implementation of innovative intentions of enterprise with history and without sufficiency of capital. Article presents a different opinion on state interventions at the market of private equity. Significant attention is devoted to development premises of private equity formal market in the middle and east Europe. Next development of private equity market in the countries of a respective region depends on measure of impact of global recession and on development assumptions of effective functioning of market. Before crisis sizeable volume of accumulated capital waits for investing, and therefore we can't expect to stubbing recession of risk capital market in the states of analyzing region now.
\end{abstract}




\section{Úvod}

Rizikový kapitál hrá dôležitú úlohu pri financovaní rýchlorastúcich malých a stredných podnikov, ktoré sú významným motorom každého národného hospodárstva. Prispievajú k zvyšovaniu inovačných aktivít, $\mathrm{k}$ rozvíjaniu konkurenčného prostredia, vytvárajú nové pracovné príležitosti a pomáhajú utvárat’ „stredný stav“, výraznú spoločenskú vrstvu, ktorej atribútom nie je iba vlastníctvo, ale aj určitý životný štýl (Fetisovová, 2004).

Štátne zásahy na trhu rizikového kapitálu sú založené predovšetkým na predpoklade nositel'ov hospodárskej politiky, že alokačný mechanizmus trhu nie je optimálny. Tento trhový nedostatok je potrebné eliminovat' štátnymi zásahmi. Súkromná sféra neposkytuje na konkurenčnom trhu dostatočný kapitál pre vybraný okruh podnikatel'ov a cenový mechanizmus nie je schopný tento stav vhodným spôsobom riešit'. Úlohou štátu je usmerňovat' fungovanie trhu rizikového kapitálu a to bud':

- dodaním dodatočného kapitálu

- alebo presunom súkromného kapitálu do malých podnikov pocitujúcich nedostatok vlastných zdrojov financovania.

Prítomnost' štátu na trhu private equity je možné len v prechodnom období v prípade zlyhania trhu. Zásahy je možné uskutočnit' len takým spôsobom, aby bolo zabezpečené prevzatie tejto úlohy trhom.

Spomalenie rastu rozvinutých krajín v poslednom období a sprísnenie regulácie trhu rizikového kapitálu zmenili orientáciu rizikových investorov v prospech rozvíjajúcich sa trhov strednej a východnej Európy. V dôsledku svetovej finančnej krízy sa však investičný rozvoj financovaný prostredníctvom úverov stal ovel’a rizikovejším a trhy nášho regiónu sa dostali do menej výhodnej pozície oproti rozvinutým trhom bez ohladu na vyššiu investičnú opatrnost' ako aj na vyššie bariéry pri získavaní dlhodobých bankových úverov. Vzhl'adom k tomu, že významný objem kapitálu nazhromaždeného pred finančnou krízou ešte len čaká na investovanie, nemôžeme $\mathrm{v}$ súčasnom období očakávat' drastickú recesiu trhu rizikového kapitálu v štátoch analyzovaného regiónu. „Zlatá epocha“ rizikových investícií sa však v dôsledku finančnej krízy skončila.

Príspevok si kladie za ciel' posúdit' rôzne smery ekonomického myslenia na štátne zásahy na trhu rizikového kapitálu a zhodnotit’ determinanty vývoja inštitucionálneho trhu private equity v strednej a východnej Európe.

K dosiahnutiu stanového ciel'a prispeli použité prvotné pramene, najmä materiály Európskej asociácie rizikového kapitálu (EVCA), Európskej banky pre obnovu a rozvoj (EBRD) a výsledky doterajších výskumov zahraničných autorov.

\section{1. Štátne intervencie na trhu rizikového kapitálu}

Prvotným ciel'om štátu je zvýšit' likviditu trhu rizikového kapitálu, ktoré by umožnilo zmiernenie kapitálovej medzery. Vlády uplatňujú rôzne riešenia na zvýšenie ponuky rizikového kapitálu pre začínajúcich malých a stredných podnikatel’ov. Sústava nástrojov sa však nepretržite mení. Štátne zásahy sa môžu uskutočňovat' priamym a nepriamym spôsobom. Nepriame nástroje zahŕňajú predovšetkým otázky zákonného usmernenia a zdaňovania. Úverové a úrokové zvýhodnenia, ako aj záruky, znamenajú určitú cestu k priamym nástrojom, kam zarad’ujeme zriadenie štátnych, verejných a zmiešaných fondov rizikového kapitálu. Vel'mi heterogénnou intervencionistickou oblast'ou je ovplyvnenie trhu rizikového kapitálu 
prostredníctvom zdaňovania. Relatívna a absolútna vel'kost' zdaňovania osobných a kapitálových príjmov môže významným spôsobom ovplyvnit' aj presun úspor $\mathrm{k}$ inštitucionálnym investorom private equity. Vel'mi citlivou oblast'ou je dvojité zdanenie, t. j. zdaňovanie kapitálových príjmov. Jeho elimináciou sa môže pozoruhodne zlepšit' efektívny kapitálový presun z prebytkového do deficitného sektora.

Názory na úlohu štátu na trhu rizikového kapitálu sa v odbornej literatúre výrazne líšia. Existujú názory výslovne podporujúce štátne zásahy. Niektorí odborníci spochybňujú aj potrebu týchto intervencií, určitá skupina odborníkov upozorňuje na negatívne účinky niektorých zásahov. Je takisto vel'mi diskutabilné aj posúdenie účinnosti štátnych intervencií, nakol'ko nie sú k dispozícii dostatočné informácie.

Podla zástancov štátnych zásahov (napríklad Aernoudt, 1999) je potreba úlohy štátu nevyhnutná. Zabezpečuje elimináciu kapitálovej medzery, pretože zmierňuje nedostatočný prístup malých podnikov k počiatočnému kapitálu. Treba vytvorit' vhodné programy, ktoré zvyšujú ponuku rizikového kapitálu súkromného sektora a prinútia rizikových investorov $\mathrm{k}$ rizikovejším malým podnikom, čím sa prispeje $\mathrm{k}$ zvyšovanie zamestnanosti v inovatívnych malých podnikoch. Podl'a predstavitel'ov tohto smeru sú štátne zásahy na európskom trhu private equity potrebné aj preto, lebo Európa má prekonat' výraznú konkurenčnú presilu voči USA. Lawton (2002) upozorňuje aj na to, že štátna pomoc na trhu rizikového kapitálu vytvára možnost' na legálnu podporu trhu.

Podl'a odporcov štátnej účasti chýba aj samotný dôkaz na existenciu trhovej nedokonalosti, ktorá by potvrdila opodstatnenost' úlohy štátu (odborníci Bank of England, 2001). Absencia štátu totiž vyvolá distorziu na trhu, pretože financuje také projekty, ktoré súkromný kapitál zamieta z dôvodu neefektívnosti. Podl'a nich štátna intervencia len zbytočne rozchádza zdroje štátneho rozpočtu.

Podl'a autorov Florida a Smith (1993) trh rizikového kapitálu nepotrebuje žiadnu pomoc, pretože je schopný vel'mi dobre reagovat' na meniace sa trhové podmienky. Pokial' štát odstráni existujúcu kapitálovú medzeru v určitom segmente trhu private equity, prispeje k zhoršeniu reakčnej schopnosti trhu. Leulex (1998) upozorňuje aj na to, že štát nie je schopný dostatočne chránit' práva rizikových investorov. Podl'a neho trh rizikového kapitálu je menší v štátoch, kde štátne zásahy sú intenzívnejšie.

Najviac sú kritizované priame nástroje štátu na podporu trhu rizikového kapitálu, t. j. založenie verejných fondov rizikového kapitálu z prostriedkov verejných rozpočtov. Podl’a O'Shea (1996) a Leleux (1998) verejné fondy vytlačia súkromné fondy z trhu, čo vyvolá spomalenie rastu súkromných fondov a v konečnom dôsledku aj trhu rizikového kapitálu. Podl'a Lernera (1999) zmiernením investičných požiadaviek verejných fondov rizikového kapitálu, môže štát financovat' také perspektívne projekty, ktoré by boli vyhoveli aj súkromným investorom. Manigart a Beuselinck (2001) uskutočnili analýzu trhu európskeho trhu rizikového kapitálu. Z výsledkov nevyplývajú žiadne znaky tzv. efektu vytláčania súkromných fondov na kontinentálnom európskom trhu rizikového kapitálu.

Odporcovia štátnej intervencie (Florida, Smith, 1993; Leleux, 1998) za najvážnejšie negatíva štátnej účasti považujú zneužívanie financovaných konštrukcií. Osobné a politické vzt'ahy a úmyselné zneužitie vedú $\mathrm{k}$ tomu, že finančná podpora formou vstupu rizikového kapitálu sa dostane k inému okruhu podnikatel'ských subjektov a nie k ciel'ovej skupine. 
Leleux (1998) d'alej zdôrazňuje skutočnost', že štátni investori a verejné fondy rizikového kapitálu sa nevedia správat' ako skutoční súkromní rizikoví investori, chýba aj vhodný motivačný systém. Podl'a neho štát preferuje predovšetkým väčšie, politicky citlivejšie podniky oproti začiatočným malým podnikom so zámerom rastu a inovatívnymi nápadmi zaručujúcimi technologický rozvoj. Vládna logika nie je totožná s ekonomickým myslením súkromných investorov, ktorí sa snažia racionálnym spôsobom diverzifikovat' svoje portfólia (Florida, Smith, 1992).

V konečnom dôsledku je diskutabilné aj hodnotenie účinnosti vládnych programov rizikového kapitálu. Podl'a Eisingera (1993) nie sú jednoznačne sformulované ciele. Podporné programy neobsahujú také kritéria, ktoré by umožnili sledovat' efektívnost' implementácie programov rizikového kapitálu. Chýbajú aj údaje, ktoré sú potrebné na hodnotenie výkonnosti verejných fondov rizikového kapitálu. Úspešnost' podporných programov v jednotlivých štátoch je vel'mi t'ažké porovnat', pretože ciele sú vel'mi rozmanité, absentujú tzv. indikátory úspešnosti programov a údaje sú niekedy nespol'ahlivé.

Na základe konfrontácie jednotlivých smerov nemôžeme jednoznačne rozhodnút', ktorá skupina autorov má presvedčivý argument. Trh rizikového kapitálu je vo väčšine európskych krajín priamo alebo nepriamo ovplyvnený štátom. Miera, obsah a spôsob intervencie závisí od hospodársko-politickej orientácie vládnucej strany ako aj od stavu konjunktúry. Najvýznamnejšiu váhu v Európskej únii však majú súkromní rizikoví investori. V štátoch strednej a východnej Európy vládne inštitúcie tvoria 30 \% rizikových investorov, v Európe len $11,8 \%$ (EVCA, 2009).

\section{Vývojové etapy trhu rizikového kapitálu v strednej a východnej Európe}

Trh rizikového kapitálu $\mathrm{v}$ regióne strednej a východnej Európy nemá dlhú históriu v porovnaní s vyspelejšími štátmi Európskej únie. Úvery potrebné na realizáciu väčších investičných príležitostí boli prístupné takisto len od začiatku prelomu tisícročia. Vzhl'adom na tieto skutočnosti bol podiel rizikových investícií na hrubom domácom produkte (HDP) pozoruhodne nižší v porovnaní so západnou Európou. Rozdiely v hodnote tohto indikátora sa však postupne znížili. Vznik manažérskych odkúpení financovaných prostredníctvom bankových úverov totiž umožnil rizikovým investorom financovat' aj také vel'ké podniky, ktoré v 90. rokoch ešte nemohli.

V sektore rizikových investícií strednej a východnej Európe existujú ešte významné rezervy. Podiel private equity investícií na HDP analyzovaného regiónu bol v roku 2002 len 0,054 \%. V Európskej únii však investície predstavili 0,277 \% hrubého domáceho produktu (Karsai, 2009), t. j. podiel investícií na HDP činil pät'násobok podielu v strednej a východnej Európe.

Nasledujúca tabul'ka uvádza komparáciu hodnôt vyššie uvedeného indikátora $v$ Európe a v krajinách strednej a východnej Európy (SVE). 
Tab. 1 - Rizikové investície a ich podiel na HDP v rokoch $2007-2009$.

\begin{tabular}{|c|c|c|c|c|c|c|}
\hline \multirow{2}{*}{ Krajina } & \multicolumn{3}{|c|}{ Rizikové investície v tisícoch $€$} & \multicolumn{3}{|c|}{ Podiel investícií na HDP v \% } \\
\hline & 2007 & 2008 & 2009 & 2007 & 2008 & 2009 \\
\hline Bosna a Hercegovina & 456 & 4208 & 6267 & 0,004 & 0,036 & 0,052 \\
\hline Bulharsko & 563374 & 90477 & 184003 & 1,950 & 0,265 & 0,543 \\
\hline Česká republika & 182368 & 434553 & 1396299 & 0,143 & 0,294 & 1,017 \\
\hline Estónsko & 36316 & 14972 & 4507 & 0,232 & 0,093 & 0,033 \\
\hline Chorvátsko & 7150 & 100875 & 28154 & 0,017 & 0,213 & 0,061 \\
\hline Litva & 23654 & 63084 & 997 & 0,111 & 0,273 & 0,005 \\
\hline Lotyšsko & 151661 & 0 & 1183 & 0,531 & 0 & 0,004 \\
\hline Macedónsko & 13500 & 0 & 14388 & 0,233 & 0 & 0,217 \\
\hline Mad'arsko & 214682 & 476104 & 213637 & 0,209 & 0,422 & 0,223 \\
\hline Moldavsko & 15050 & 0 & 0 & 0,462 & 0 & 0 \\
\hline Čierna Hora & 0 & 25000 & 0 & 0 & 0,809 & 0 \\
\hline Pol'sko & 440715 & 633210 & 268094 & 0,141 & 0,167 & 0,089 \\
\hline Rumunsko & 318089 & 289371 & 220881 & 0,239 & 0,205 & 0,189 \\
\hline Slovenská republika & 24700 & 31145 & 0 & 0,040 & 0,046 & 0 \\
\hline Slovinsko & 1554 & 2853 & 79130 & 0,004 & 0,008 & 0,227 \\
\hline Srbsko & 105718 & 8402 & 0 & 0,649 & 0,049 & 0 \\
\hline Ukrajina & 245021 & 305745 & 38244 & 0,230 & 0,232 & 0,045 \\
\hline SVE & 2344007 & 2479998 & 2455783 & $\mathbf{0 , 1 9 0}$ & 0,201 & 0,239 \\
\hline Európa & 71445012 & 52674787 & 22690468 & 0,570 & 0,394 & 0,181 \\
\hline
\end{tabular}

Zdroj: Vlastné spracovanie podl'a Central and Eastern Europe Statistics 2009. Brussels: European Private Equity \& Venture Capital Association, 2010. pp. 11.

$\mathrm{Na}$ základe údajov tabul'ky 1 môžeme konštatovat', že ostré rozdiely $\mathrm{v}$ relatívnych indikátoroch Európy a štátov strednej a východnej Európy sa postupne znižujú. Pri komparácii uvedených syntetických údajov však máme brat' do úvahy, že vyššia hodnota niekol'ko manažérskych odkúpení môže vel'mi pozitívne ovplyvnit' ročnú hodnotu celkových investícií. Ako príklad spomeňme len Bulharsko v roku 2007, kedy rizikové investície predstavovali 1,95 \% HDP z dôvodu realizácie vyšších hodnôt manažérskych odkúpení.

Výsledky analýz private equity investícií v pomere k HDP ukazujú, že stredná a východná Európa už nepatrí pod európsky priemer. Kým podiel rizikových investícií na HDP strednej a východnej Európy predstavoval v roku 2007 len tretinu priemernej hodnoty Európy, situácia sa v roku 2009 obrátila.

V roku 2009 podiel private equity investícií na hrubom domácom produkte v regióne strednej a východnej Európy bol 0,239 \%, a európsky priemer len 0,181 \%. Táto hodnota (podobne ako to bolo v prípade Bulharska v roku 2007) je významne ovplyvnená výnimočnými private equity investíciami v Českej republike (malý počet vel'kých investícií), kde rizikové investície sa medziročne zvýšili o $221 \%$ oproti roku 2008. Private equity investície však zaznamenali v hlavných západných európskych trhoch pozoruhodný pokles. V dôsledku finančnej a hospodárskej krízy rizikové investície Európy poklesli o 56,62 \% oproti roku 2008, čo v absolútnych sumách predstavuje 29,98 mld. €. Okrem toho aj Mad'arsko, Pol'sko a Ukrajina 
zaznamenali podobný pokles private equity investícií, čo zdôrazňuje aj fakt, že vzostupný trend nie je typický pre celý región SVE. Pokial' porovnáme podiely rizikových investícií na HDP Európy a strednej a východnej Európy bez Českej republiky, zistíme, že v roku 2009 tento indikátor predstavuje $0,119 \% \mathrm{v}$ regióne SVE, t. j. len 65,75 \% európskeho priemeru. Pre trh private equity SVE je typické, že investičná činnost' je vysoko koncentrovaná v piatich krajinách. Efektívnejšie fungujúce trhy má Bulharsko, Česká republika, Mad’arsko, Pol'sko a Rumunsko, ktoré „produkujú“ $93 \%$ z celkovej hodnoty private equity investícií v strednej a východnej Európe. V týchto štátoch pôsobí totiž $73 \%$ z celkového počtu spoločností rizikového kapitálu strednej a východnej Európy.

Graf 1 - Vývoj podielov rizikových investícií na HDP.

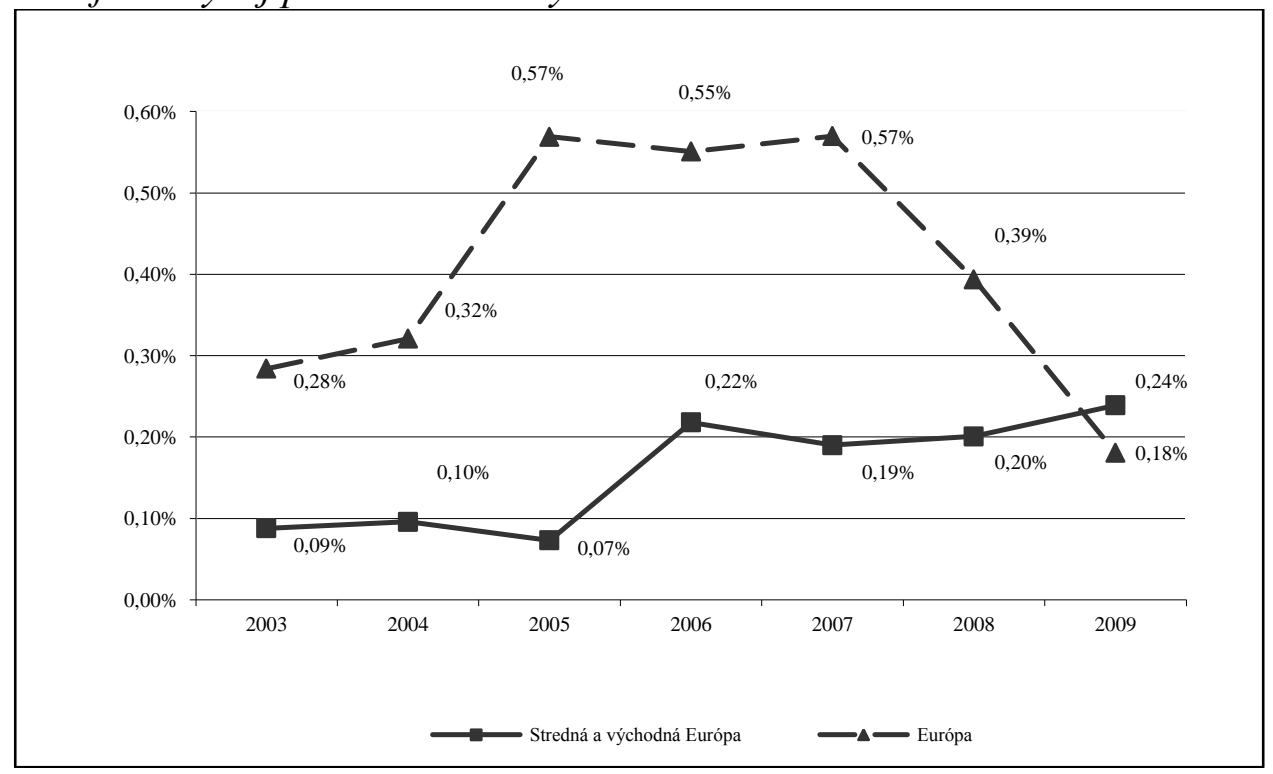

Zdroj: Vlastné spracovanie podl'a Central and Eastern Europe Statistics 2009.

Brussels: EVCA, 2010. pp. 11.

Je však zrejmé, že rok 2009 bol výnimočným rokom (graf 1). Úroveň investícií $\mathrm{v}$ analyzovanom regióne je nad európskym priemerom. Hoci rozsah trhu private equity v jednotlivých štátoch SVE klesá, ale tento pokles nie je taký markantný ako na západných európskych trhoch, investície v regióne strednej a východnej Európy zostali stabilné na 2,5 mld. € v roku 2009.

Na základe štúdie Európskej banky pre obnovu a rozvoj (Transition report 2006: finance in transition) môžeme vývoj trhu rizikového kapitálu strednej a východnej Európy rozdelit' do šiestich vývojových etáp.

Prvá etapa trvala od zmeny režimu až do polovice 90. rokov. V tomto období mali významné postavenie tzv. globálne fondy investujúce kapitál zahraničných vládnych organizácií a štátne fondy. Hodnota týchto štátnych fondov sa pohybovala okolo 50 mil. USD. V rámci transakcií mali významné postavenia aj investičné príležitosti v procese privatizácie.

Druhá etapa trvala do konca 90. rokov, ktorú charakterizovali najmä aktivity regionálnych fondov. Okrem toho boli založené aj menšie štátne fondy a niekol'ko sektorových fondov. Fondy boli už väčšie, výška spravovaného kapitálu predstavovala 100 až 200 mil. USD. Investície sa orientovali na financovanie rozvoja podniku. Začala sa aj konsolidácia trhu rizikového kapitálu regiónu SVE. 
Tretia etapa trvala až po vypnutí technologickej bubliny na prelome tisícročia. Epochu charakterizovala rýchla expanzia. Regionálne fondy mali nad’alej väčšiu váhu. Do popredia sa však dostáva financovanie technologického rastu. Výška spravovaného kapitálu jednotlivých fondov dosiahla 250 - 300 mil. USD. Na trhu vystupovali predovšetkým inštitucionálni investori, ako investori vel'kých finančných inštitúcií a investori regiónu SVE. Hlavnými financovanými oblast’ami boli technológie, informačné technológie a médiá.

Podl'a analýzy Európskej banky pre obnovu a rozvoj uskutočnenej v roku 2006 môžeme štvrtú etapu časovo vymedzit' na roky 2001 - 2006. Toto obdobie je charakterizované racionalizáciou trhu private equity. $\mathrm{V}$ týchto rokoch sa vedl'a regionálnych a štátnych fondov objavili aj špecializovaní investori. Financovanie sa rozš́rilo na manažérske odkúpenia, financované boli i nad'alej - ale už v menšej miere - podniky vo fáze rozvoja. Aj ked' európsky trh private equity zaznamenal $\mathrm{v}$ týchto rokoch rýchly vývoj, prístup malých podnikov k externým zdrojom vo forme predštartovacieho a štartovacieho kapitálu zostal nad'alej neriešeným problémom. Hlavnou orientáciou trhu private equity ( $\mathrm{v}$ dôsledku zmiernenia rizika) sú investície do neskorších štádií rozvoja podnikov a financovanie špeciálnych typov akvizícií (management buy-out).

Šoky spôsobené finančnou a hospodárskou krízou v druhej polovici roka 2007 zásadne zmenili aj investičné rozhodnutia rizikových investorov, do popredia sa dostáva požiadavka diverzifikácie portfólia rizikových investícií. V dôsledku spomalenia rastu trhu private equity rozvinutých krajín a sprísnenia trhových regulačných opatrení investori boli nútení hl'adat' nové investičné príležitosti $\mathrm{v}$ iných krajinách. Najlepšou vol'bou sa ukázali trhy strednej a východnej Európy, predovšetkým však trhy nových členských štátov EÚ. Ide totiž o menej rizikové krajiny s rastúcim trhom a novými investičnými príležitost'ami, ktoré „,z krátkodobého hl'adiska menšou mierou pocit’ovali negatívne dopady finančnej a hospodárskej krízy“ (Karsai, 2009, s. 48).

V piatej etape rozvoja trhu private equity SVE sa posilňoval proces zhromaždenia a investovania kapitálu vanalyzovanom regióne (graf 2). V roku 2007 vznikol prvý a v nasledujúcom roku druhý regionálny fond s majetkom prevyšujúcim $1 \mathrm{mld}$. $€$. Progresívny rast hrubého domáceho produktu štátov daného regiónu a s tým súvisiaca vyššia spotreba, vybudovaná infraštruktúra a investičné príležitosti v konglomerátoch upevňujúcich svoje postavenia signalizovali lákajúcu úroveň výnosov pre potenciálnych investorov.

Začiatok šiestej etapy bol signalizovaný tým, že private equity index dôvery strednej a východnej Európy (Central Europe Private Equity Confidence Index) zverejnený poradenskou spoločnost'ou Deloitte v júni 2008 ukázal zmenený názor rizikových investorov o danom regióne. V súlade $\mathrm{s}$ globálne zhoršujúcimi podmienkami trhu private equity pozoruhodne poklesla aj dôvera stredoeurópskych investorov. Index dôvery sa zostavuje od roku 2003, a to dvakrát za rok. Bázickou hodnotou je 100, ktorá zodpovedá hodnote za marec 2003. Významné zvýšenie sme mohli vidiet' v apríli 2007, kedy private equity index nadobudol historicky najvyššiu hodnotu (159 bodov). V júni 2008 však hodnota indexu poklesla na 48 bázických bodov. Rizikoví investori totiž na začiatku predpokladali, že finančná kríza bude mat' z krátkodobého hl'adiska miernejší negatívny dopad na krajiny nových členských štátov a predpokladali aj intenzívnejší ekonomický rast oproti krajinám s rozvinutým trhom private equity. V skutočnosti sa však zhoršila dostupnost' dlhodobých úverov a znížila sa aj pravdepodobnost' stabilnej miery výnosu. Rizikové investície a s nimi súvisiace transakcie sa významne znížili, fondy rizikového kapitálu prestali investovat' do 
nových podnikov. Zvýšili len svoje podiely v podnikoch, ktoré boli pôvodne zastúpené v ich portfóliách.

V súčasnej dobe sa trh rizikového kapitálu strednej a východnej Európy nachádza na začiatku siedmej etapy. Na základe správy poradenskej spoločnosti Deloitte (Leading the way or jumping the gun? Central Europe Private Equity confidence survey) publikovanej na konci roka 2009 sa PE index strednej Európy zvýšil na 117 bázických bodov, čo predstavuje oproti roku 2008 rast o 143 \%. Ukazovatel' vypovedá o zvýšení dôvery potenciálnych rizikových investorov. Je to spôsobené aj určitou stagnáciou na trhu rizikového kapitálu analyzovaného regiónu, ktorú v porovnaní s vel'mi negatívnym vývojom západného trhu private equity môžeme považovat' aj za pozitívny jav (graf 2). V predchádzajúcich textoch sme spomenuli, že rozsah trhu private equity v niektorých štátoch SVE klesá (Pobaltské krajiny, Mad'arsko, Slovensko, Pol'sko, Ukrajina), tento pokles však nie je taký progresívny ako na západných európskych trhoch.

Graf 2-Vývoj rizikových investícií v SVE v rokoch $2003-2009$.

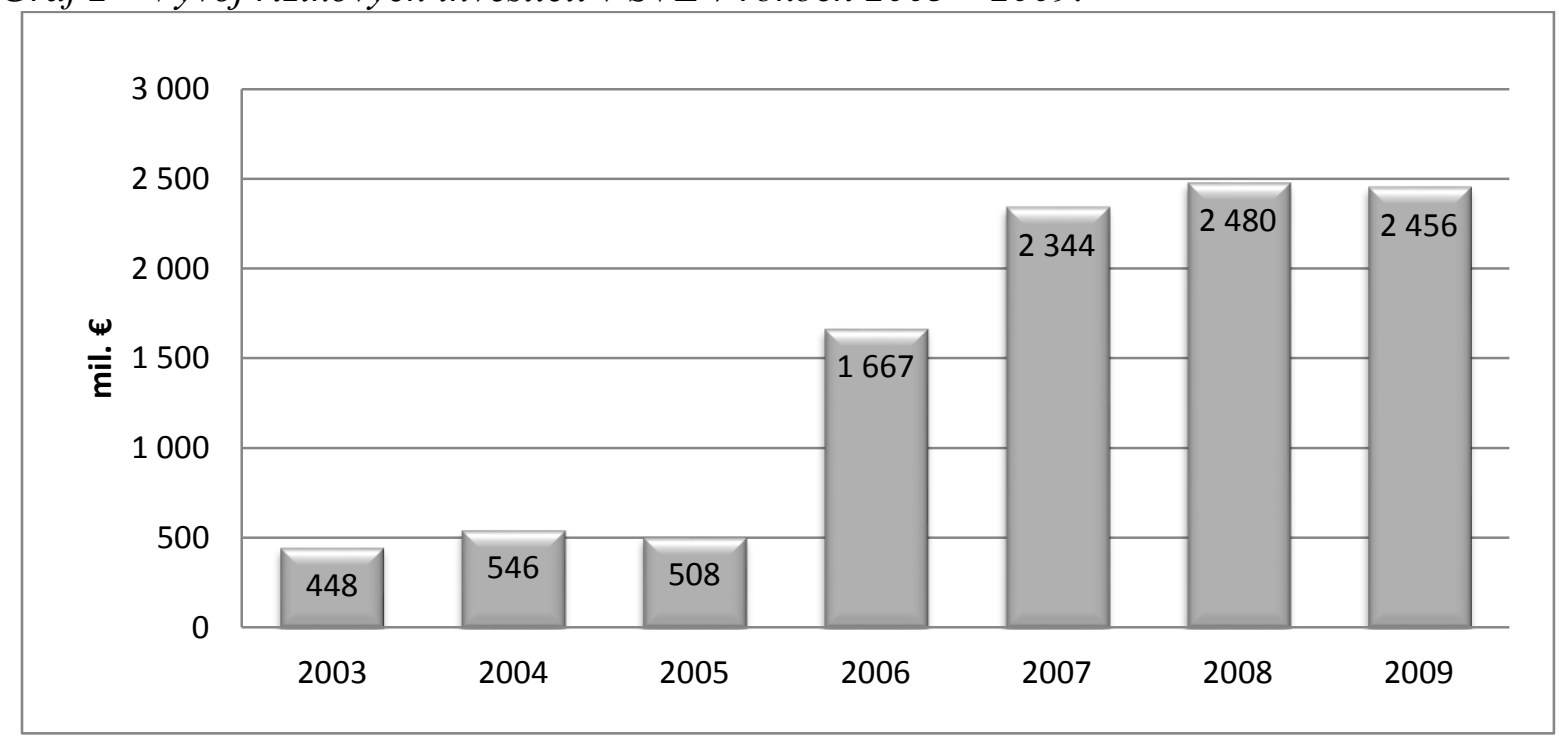

Zdroj: Vlastné spracovanie podl'a Central and Eastern Europe Statistics 2009. Brussels: EVCA, 2010. pp. 7.

Kým v štátoch SVE sa v roku 2008 rizikové investície zvýšili o 5 \%, Európa zaznamenala pokles o $27 \%$. Pokles bol vyvolaný poklesom investícií na trhoch západnej Európy. Určitú stagnáciu (graf 2) môžeme pozorovat' na trhoch SVE v roku 2009. Rizikové investície sa znížili len o $1 \%$. Na druhej strane však investičné aktivity Európy poklesli o viac ako $57 \%$.

\section{Rizikoví investori na trhu private equity v strednej a východnej Európe}

Do podnikov SVE vstupuje predovšetkým zahraničný rizikový kapitál a private equity. Hodnota nazhromaždeného kapitálu v roku 2002 predstavovala len 234 mil. $€$ a o dva roky sa zvýšila na 496 mil. $€$, čo je takmer 112 \% nárast. Fundraising v rokoch 2005 až 2007 zaznamenal vel'mi progresívny rast, ktorý znázorňuje aj graf 3. Na konci roka 2007 hodnota zhromaždeného kapitálu činila viac ako 3983 mil. €, a tým predstavoval 17-násobok fundraisingu v roku 2002. Od tohto momentu sa však situácia zásadne zmenila. Trh private equity SVE vstúpil do šiestej fázy svojho vývoja, ktorú charakterizovala nízka dôvera rizikových investorov meranej pomocou PE indexu spoločnosti Deloitte. Zhromažd'ovanie rizikového kapitálu sa výrazne spomalilo a fondy prestali investovat' do nových podnikov. 
Fundraising pre regióny strednej a východnej Európy sa v roku 2009 znížil o $85 \%$ oproti minulému roku a dosiahol len priemernú úroveň rokov 2003 a 2004 (378 mil. €). Tento pokles je však v súlade s priemerným $80 \%$ poklesom európskeho fundraisingu z 81,4 mld. $€$ na 16,1 mld. $€$. Proces zhromažd'ovania kapitálu sa v dôsledku finančnej krízy výrazne spomalil aj v štátoch SVE. Vzhl'adom na vel'ký objem kapitálu fondov private equity, ktorý bol nazhromaždený ešte v období rokov 2005 až 2007, rizikové investície SVE zostali nad’alej na stabilnej úrovni.

Graf 3 - Vývoj fundraisingu v regióne SVE v rokoch $2002-2009$.

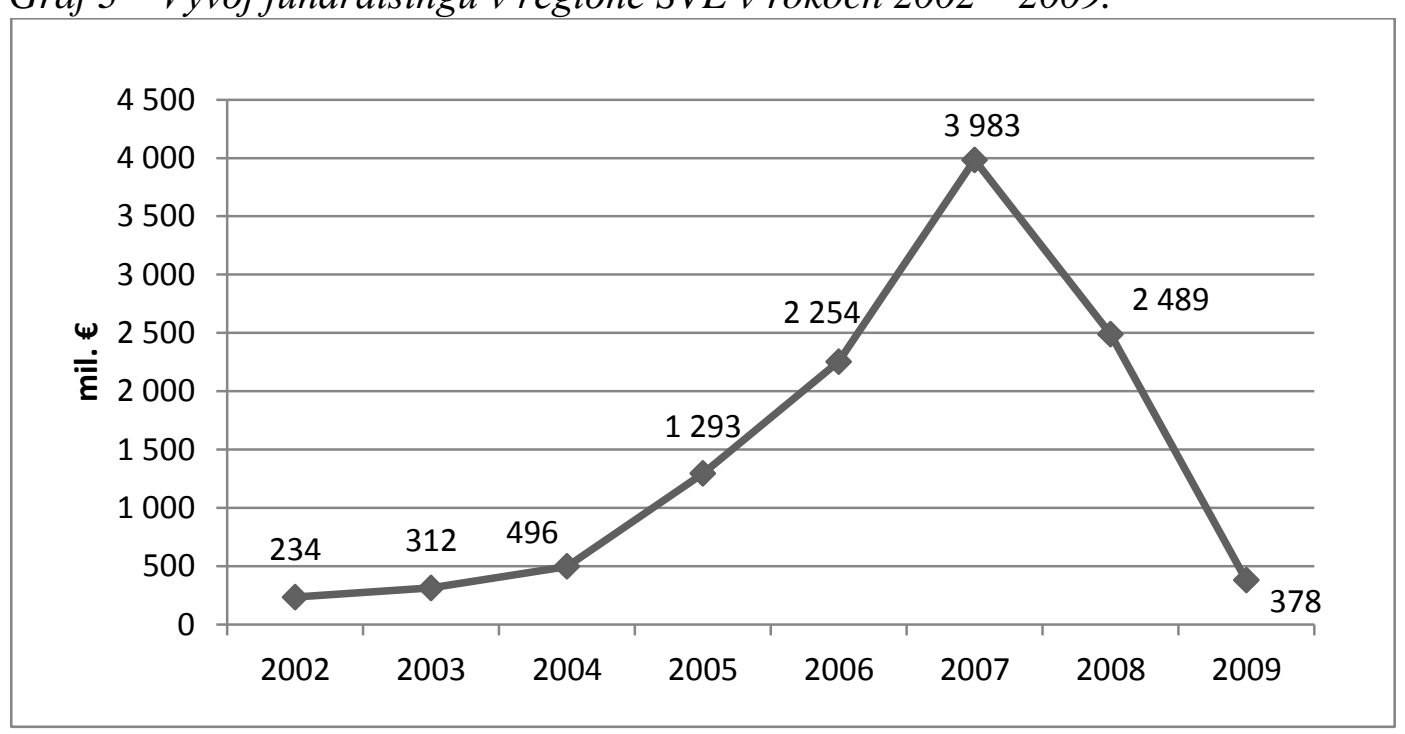

Zdroj: Vlastné spracovanie podl'a Central and Eastern Europe Statistics 2009. Brussels : EVCA, 2010. pp. 4.

Istým problémom je však silná orientácia trhu private equity na financovanie špeciálnych typov akvizícií. Akútny nedostatok vlastných zdrojov financovania začínajúcich malých a stredných podnikov je nad’alej otvorenou otázkou.

Kapitál fondov private equity v krajinách SVE pochádza väčšinou zo západoeurópskych a severoamerických štátov, podl'a údajov za rok 2009 len 17,7 \% bol domáci kapitál. Na stredoeurópskom trhu private equity vystupujú predovšetkým inštitucionálni investori. Podl'a najnovších údajov EVCA (2009), približne $30 \%$ rizikových investorov sú vládne inštitúcie, banky majú len o polovicu menej, $14 \%$ zastúpenie v skupine rizikových investorov. Poist'ovne a fondy fondov majú rovnaký, $10 \%$ podiel a obchodní anjeli (neinštitucionálni investori) cca. 10,5 \%. Penzijné fondy a korporátni investori mali len nepatrný podiel.

\section{Formy rizikových investícií v strednej a východnej Európe}

Vplyv trhu rizikového kapitálu na rozvoj ekonomiky závisí od toho, v akej miere rizikový kapitál financuje štart a expanziu podnikania. Je to základnou podmienkou napomáhania inovačných aktivít $\mathrm{v}$ malých a stredných podnikoch. Rizikové investície $\mathrm{v}$ strednej a východnej Európe boli v počiatkoch zamerané na financovanie rozvoja podnikania. Podiel rozvojového financovania na rizikových investíciách v strednej a východnej Európe bol významnejší než na západe. Bolo to vyvolané predovšetkým rýchlym rastom ekonomík analyzovaného regiónu. V ostatných rokoch sa situácia zásadne zmenila v prospech 
financovania akvizícií vel'kých podnikov. Zvýšenie rizikových investícií je výsledkom markantného rastu transakcií súvisiacich s manažérskymi odkúpeniami.

Tab. 2 - Private equity investície v SVE a v Európe, 2009.

\begin{tabular}{|c|c|c|c|c|}
\hline \multirow[t]{2}{*}{ Formy private equity investície } & \multicolumn{2}{|c|}{$\begin{array}{c}\text { Investície } \\
\text { v strednej a východnej } \\
\text { Európe }\end{array}$} & \multicolumn{2}{|c|}{$\begin{array}{l}\text { Investície } \\
\text { v Európe }\end{array}$} \\
\hline & $\mathrm{v}$ tis. $€$ & $\%$ podiel & $\mathrm{v}$ tis. $€$ & $\%$ podiel \\
\hline Predštartovací kapitál (seed) & 1561 & 0,1 & 144093 & 0,6 \\
\hline Štartovací kapitál (start-up) & 10562 & 0,4 & 1848213 & 8,1 \\
\hline Financovanie neskoršieho rozvoja (later-stage) & 31295 & 1,3 & 1829421 & 8,1 \\
\hline Rizikový kapitál spolu & 43418 & 1,8 & 3821727 & 16,8 \\
\hline Rozvojový kapitál (expansion/growth) & 390861 & 15,9 & 4493697 & 19,8 \\
\hline Revitalizačný kapitál (turnaround) & 6800 & 0,3 & 683160 & 3,0 \\
\hline Náhradný kapitál (replacement) & 170745 & 7,0 & 1774590 & 7,8 \\
\hline Manažérske odkúpenia (buyout) & 1843960 & 75,1 & 11917294 & 52,5 \\
\hline Spolu v roku 2009 & 2455783 & 100,0 & 22690468 & 100,0 \\
\hline Spolu v roku 2008 & 2479998 & - & 52674787 & - \\
\hline
\end{tabular}

Zdroj: Central and Eastern Europe Statistics 2009. Brussels: EVCA, 2010. pp. 13.

Z tabul'ky 2 vyplýva, že fondy private equity v štátoch strednej a východnej Európy (podobne ako v západných krajinách Európy) sa zaoberajú hlavne financovaním špeciálnych typov akvizícií. Rozvojové financovanie má menší podiel $(15-20 \%)$. Štruktúra investovaného kapitálu sa v porovnaní s minulými obdobiami výrazne nemenila. Podiel predštartovacieho kapitálu v roku 2005 bol v Európe $0,2 \%$ a SVE $0 \%$, podiel štartovacieho kapitálu $5 \%$ v Európe a 1,8 \% v SVE, podiel rozvojového kapitálu v Európe 21,8 \%, v SVE 25,9 \%.

Začínajúce malé a stredné podniky majú na základe vyššie uvedených údajov rok čo rok väčšie problémy pri získavaní alternatívnych externých vlastných zdrojov financovania. Napriek jednotlivým krokom Európskej únie zameraným na zmiernenie bariér malých a stredných podnikov na získavanie rizikového kapitálu (implementácia Akčného plánu rizikového kapitálu EÚ, zavedenie finančných nástrojov politiky malých a stredných podnikov EÚ - Fond pre rýchlorastúce a inovačné malé a stredné podniky, JEREMIE) sa situácia z pohl'adu štatistických údajov nezlepšila. Potvrdila sa teda hypotéza druhej kapitoly o nižšej účinnosti štátnych zásahov. V duchu týchto skutočností, prístup k finančným zdrojom potrebným k založeniu, štartu a začiatočného rozvoja malých podnikov čoraz vo väčšej miere bude závisiet' od atraktívneho fungovania neinštitucionálneho trhu rizikového kapitálu.

Dominantný $75 \%$ podiel manažérskych odkúpení na private equity investíciách je výsledkom niekol'kých faktorov:

- pri financovaní špeciálnych typov akvizícií majú transakcie ovel’a vyššiu hodnotu než pri financovaní expanzie podniku;

- financovanie vel'kých a známych podnikov je menej rizikové v porovnaní s malými a strednými podnikmi; 
- vel'ké investície boli z ekonomického hl'adiska efektívne aj preto, lebo čast' transakcií bolo možné financovat' z úverov, ktoré boli zabezpečené majetkom už odkúpeného podniku;

- trhy rizikového kapitálu strednej a východnej Európy sa pridržiavali aktuálnych svetových trendov na vyspelých európskych a svetových trhoch.

Pozitívny ekonomický vplyv rizikového kapitálu pocit’ovali hlavne jednotlivé odvetvia, do ktorých tento alternatívny zdroj vstupoval. V období tzv. internetového boomu dostali významný kapitál hlavne informačno-technologické odvetvia. Objem získaného kapitálu však bol ovel'a nižší než v Spojených štátoch amerických alebo v západnej Európe. Na prelome tisícročia sa do popredia dostali určité oblasti telekomunikácie, káblovej služby a infraštruktúry. Rizikoví investori videli vel'ké príležitosti aj v takých oblastiach, ktoré sú úzko spojené so spotrebou obyvatel'stva, napr. maloobchod, finančné služby, priemysel vol'ného času a zábavný priemysel.

Fondy private equity svoju pozornost' sústredili na telekomunikácie a médiá, pretože počítali s tým, že rastúci dôchodok obyvatel'stva automaticky vyvolá rast dopytu po vyššie uvedených službách. Najväčší objem kapitálu sa do roku 2004 sústredil do telekomunikácií, na výrobu spotrebných predmetov, do sektora služieb a finančných služieb.

Najväčší objem kapitálu v roku 2009 vstúpil do podnikov produkujúcich spotrebné predmety (35\% private equity), do telekomunikácií $(21,6 \%)$ a do sektora finančných služieb $(10,2 \%)$.

\section{Výhl'ady trhu private equity v strednej a východnej Európe}

Budúci vývoj trhu private equity SVE závisí od miery dopadov svetovej recesie a od predpokladov efektívneho fungovania trhu v jednotlivých štátoch SVE. V dôsledku svetovej finančnej krízy sa rast financovaný z úverov stal synonymom rizikovosti. Rozvojové trhy vrátane trhov SVE sa dostali do úzadia oproti vyspelým trhom, a to aj bez ohl'adu na vyššiu investičnú opatrnost', na t'ažšie dostupné rozvojové úvery a na vyššie úrokové sadzby. Stredná a východná Európa je mimoriadne bezbranná voči nepriaznivým vplyvom globálnej krízy, pretože práve tento región ukazuje najväčšiu závislost' do zahraničného kapitálu. Najrýchlejší prílev kapitálu bol práve tu. Tu je aj najväčší deficit bežného účtu platobnej bilancie, a tu je najtypickejšie, že banky sú v zahraničnom vlastníctve (Karsai, 2009). Významné rozdiely možno zároveň vidiet' $v$ intenzite ekonomického rastu, $v$ miere zadlženosti a vo vel'kosti domáceho dopytu jednotlivých krajín SVE. Zranitel'nost' jednotlivých ekonomík d'alej zvyšujú aj osobitné problémy (napríklad vysoká vonkajšia zadlženost' Mad'arska, obrovská výška devízových úverov v Pol'sku a Mad'arsku alebo vysoký deficit bežného účtu platobnej bilancie v pobaltských krajinách).

Vel'ký objem kapitálu, ktorý bol nazhromaždený pred finančnou krízou, ešte len čaká na investovanie a preto nemôžeme v súčasnom období čakat' drastickú recesiu trhu private equity SVE. Tvorba nových fondov sa však určite spomaluje a znižuje sa aj objem rizikových investícií. Sprísnenie úverových podmienok pravdepodobne znižuje aj objem manažérskych odkúpení. Rizikoví investori $\mathrm{v}$ budúcnosti určite zmenia svoju politiku pri výbere potenciálnych partnerských podnikov. Môžeme počítat' aj s tým, že rizikoví investori podobne ako ich západoeurópski partneri - vylúčia zo svojho portfólia podniky takého odvetvia, ktoré sú silne závislé od zmeny konjunktúry. Z ciel'ovej skupiny rizikových investorov pravdepodobne vystúpia podniky stavebného priemyslu, automobilového 
priemyslu, chemického priemyslu a médií (Vigh, 2008). Lákajúcou oblast'ou však budú nad’alej informačné technológie, telekomunikácie a sektor zdravotníctva.

\section{Záver}

Trh private equity strednej a východnej Európy počas svojho krátkeho fungovania prešiel významnými zmenami, o tom svedčia aj štatistické údaje Európskej asociácie rizikového kapitálu. Rizikové investície sa v štátoch strednej a východnej Európy zvýšili o $5 \%$ v roku 2008, Európa však zaznamenala pozoruhodný pokles až o 27 \%. Vplyvom globálnej krízy sa situácia zmenila. Kým na trhoch rizikového kapitálu SVE možno pozorovat' istú stagnáciu, investície v Európe poklesli až o $57 \%$ oproti predchádzajúcemu roku. Z pohl'adu mechanizmu svojho fungovania, funkcie a efektívnosti sa trh rizikového kapitálu SVE viac podobá na západoeurópsky trh. Vzhl'adom na dopady finančnej a hospodárskej krízy je otvorenou otázkou, či vývojový trend charakterizujúci predchádzajúce obdobia bude pokračovat' alebo skončí významný záujem rizikových investorov.

Príspevok bol spracovaný na Katedre podnikových financií Fakulty podnikového manažmentu Ekonomickej univerzity v Bratislave v rámci výskumnej úlohy VEGA č. 1/1071/12 „Nové trendy v oblasti rozpočtovo-kapitálových a finančných rozhodnutí a vplyv na hodnotu podniku“".

\section{Literatúra:}

[1] AERNOUDT, R. European policy towards venture capital: myth or reality? Venture Capital: An International Journal of Entrepreneurial Finance. 1999, Vol. 1, No. 1, s. 47-58. ISSN 1369-1066.

[2] ATZMÜLlER, A.; GAEDKE, K.; GYENGE, E.; KROPF, M.; PINTER, G.; WEIGL, A. Innovative Finanzierung im klein- und Mittelbetrieb. Wien: Verlag für Technische Universität Graz, 2004. 200 s. ISBN 3-7041-0341-1.

[3] Central and Eastern Europe Statistics 2009. An EVCA Special Paper. [on-line]. Brussels: European Private Equity \& Venture Capital Association, July 2010. 36 s. [cit. 2011-04-12]. Dostupné na WWW: <http://www.psik.org.pl/new/docs/EVCA_CEE_ Statistics_2009_July_2010.pdf>.

[4] EISINGER, P. State venture capitalism, state politics, and world of high-risk investment. Economic Development Quarterly. 1993, Vol. 7, No. 2, s. 131-139. ISSN 0891-2424.

[5] EVCA Barometer. [on-line]. Brussels: European Private Equity \& Venture Capital Association, Issue 71 Spring 2010. 21 s. [cit. 2011-04-18]. Dostupné na WWW: <http://www.evca.eu/uploadedFiles/Home/Knowledge_Center/EVCA_Research/Barom eter/April_2010.pdf>.

[6] EVCA Barometer. [on-line]. Brussels: European Private Equity \& Venture Capital Association, Issue 72 Summer 2010. 24 s. [cit. 2011-05-01]. Dostupné na WWW: <http://www.evca.eu/uploadedFiles/Home/Knowledge_Center/EVCA_Research/Barom eter/September_2010.pdf $>$.

[7] FETISOVOVÁ, E.; VLACHYNSKÝ, K.; SIROTKA, V. Financie malých a stredných podnikov. Bratislava: Iura Edition, 2004. 206 s. ISBN 80-89047-87-4.

[8] FETISOVOVÁ, E. Rizikový kapitál - alternatívny zdroj financovania podnikov. Bratislava: Vydavatel'stvo Ekonóm, 2007. 96 s. ISBN 978-80-225-2289-2. 
[9] FETISOVOVÁ, E.; NAGY, L. Úlohy trhu rizikového kapitálu pri financovaní európskych malých a stredných podnikov. Nová ekonomika. 2007, roč. 6, č. 2, s. 15-21. ISSN 1336-1732.

[10]Financing of Technology-Based Small Firms. [on-line]. London: Bank of England, February 2001, 106 s. [cit. 2011-04-15]. Dostupné na WWW: <http://www.bankof england.co.uk/publications/financeforsmallfirms/hightech2001.pdf>.

[11]FLORIDA, R.; SMITH, D. F. Keep the Government Out of Venture Capital. [on-line]. Issues in science and technology. 1993, s. 61-68. ISSN 1092-120. [cit. 2011-05-22]. Dostupné na WWW: <http://www.creativeclass.com/rfcgdb/articles/1993-Issues_In_ Science_And_Technology-Keep_The_Government_Out_Of_Venture_Capital.pdf $>$.

[12] Global trends in venture capital: 2009 global report. [on-line]. Deloitte Touche Tohmatsu, 2009. 36 s. [cit. 2011-04-30]. Dostupné na WWW: <http://www.deloitte. com/assets/DcomGlobal/Local\%20Assets/Documents/tmt_2009vdsurvey.pdf >.

[13]KARSAI, J. Mit keres az állam a kockázatitőke-piacon? (A kockázati tőke állami finanszírozása Magyarországon) Közgazdasági Szemle. 2002. november, XLIX. évf., s. 928-942. ISSN 0023-4346.

[14]KARSAI, J. Kifelé a zsákutcábó. Állami kockázati tőke és innováció. Közgazdasági Szemle. 2007. december, LIV. évf., s. 1085-1112. ISSN 0023-4346.

[15]KARSAI, J. Az aranykor vége. A kockázatitőke-ágazat fejlődése Közép-KeletEurópában. Közgazdasági Szemle. 2009. január, LVI. évf., s. 46-68. ISSN 0023-4346.

[16]LAWTON, TH. C. Missing the target: Assessing the role of government in bridging the European equity gap and enhancing economic growth. Venture Capital: An International Journal of Entrepreneurial Finance. 2002, Vol. 4, No. 1, s. 7-23. ISSN 1369-1066.

[17] Leading the way or jumping the gun? Central Europe Private Equity confidence survey. [on-line]. Deloitte Central Europe, October 2009. 12 s. [cit. 2011-04-29]. Dostupné na WWW: <http://www.deloitte.com/assets/Dcom-CzechRepublic/Local\%20Assets/Docu ments/Private\%20Equity/ce_private_equity_survey_Oct_09.pdf $>$.

[18]LELEUX, B.; SURLEMONT, B.; WACQUIER, H. State versus Private Venture Capital: Cross-Spawning or Crowding Out? A Pan-European Empirical Examination. Summary. [on-line]. Babason College, 1998. [cit. 2011-04-28]. Dostupné na WWW: <http://www.babson.edu/entrep/fer/papers98/ XXII/XXII_D/XXII_D.html>.

[19]LERNER, J. The government as venture capitalist: the long-run impact of the SBIR program. Summary. [on-line]. Journal of Business. 1999, Vol. 72, No. 3, s. 285-318. ISSN 0021-9398. [cit. 2011-04-19]. Dostupné na WWW: <http://www.jstor.org/stable/ 10.1086/209616>.

[20] MAJKOVÁ, M. Možnosti financovania malých a stredných podnikov v SR. Brno : Tribun EU, 2008. 204 s. ISBN 978-80-7399-590-4.

[21]MANIGART, S.; BEUSELINCK, CH. Supply of Venture Capital by European Governments. Working Paper. [on-line]. Gent: Universiteit Gent, Faculteit Economie en Bedrijfskunde, 2001. 27 s. [cit. 2011-05-19]. Dostupné na WWW: <http://www.feb. ugent.be/nl/Ondz/wp/Papers/wp_01_111.pdf>.

[22] O'SHEA, M. Venture Capital in OECD Countries. Financial Market Trends. 1996, No. 63, s. 15-37. ISSN 0378-651X.

[23] Transition report 2006: finance in transition. [on-line]. London: European Bank for Reconstruction and Development, 2006. 204 s. ISBN 978-1898802280-204. [cit. 201104-20]. Dostupné na WWW: <www.ebrd.com/downloads/research/transition/TR06.p df>.

[24] VÍGH, GY. ZS. A kockázati tőke válságreakciói. Világgazdaság. 2008. október 10., s. 13. ISSN 1418-1525. 
JEL G24, G28, M13

doc. Ing. Elena Fetisovová, CSc.

Katedra podnikových financií

Fakulta podnikového manažmentu

Ekonomická univerzita v Bratislave

Dolnozemská cesta 1/b, 85235 Bratislava

Tel.: +421267295671

efetisov@dec.euba.sk

Ing. Eduard Hyránek, PhD.

Katedra podnikových financií

Fakulta podnikového manažmentu

Ekonomická univerzita v Bratislave

Dolnozemská cesta 1/b, 85235 Bratislava

Tel.: +421267295669

hyranek@euba.sk

Ing. Ladislav Nagy, PhD.

Katedra podnikových financií

Fakulta podnikového manažmentu

Ekonomická univerzita v Bratislave

Dolnozemská cesta 1/b, 85235 Bratislava

Tel.: +421267295659

ladislav.nagy@euba.sk 